\title{
Articles
}

\section{Survey of the Teaching of Pronunciation in Adult ESL Programs in Canada, 2010}

\author{
Jennifer A. Foote, Amy K. Holtby, \\ and Tracey M. Derwing
}

This follow-up study reexamines the state of the teaching of pronunciation in ESL classes across Canada. The purpose of the survey was twofold: to gain a snapshot of current practices and to compare this with the picture of 10 years ago. We based the current work on Breitkreutz, Derwing, and Rossiter's (2001) survey asking teachers about resources, approaches, and beliefs about teaching pronunciation. We also asked for background information about the instructors' formal education and teaching experience. For the most part, instruction in pronunciation in Canada has not changed substantially in the last decade. More training opportunities are available, although these are still not enough according to many of our respondents. The number of pronunciation courses offered in English-as-asecond-language (ESL) programs has also increased. Teachers' beliefs about pronunciation instruction remained largely the same, with a similar focus on suprasegmentals and segmentals. However, we did find a slight difference in how teachers approached these two aspects of pronunciation. Ten years ago, teachers reported emphasizing both aspects in class, whereas today there seemed to be a slightly greater focus on segmentals. Finally, we offer several recommendations for TESL programs, ESL programs, and ESL instructors.

Ce suivi porte un nouveau regard sur l'état de l'enseignement de la prononciation dans les cours d'ALS de par le Canada. L'enquête avait deux objectifs : obtenir un aperçu des pratiques courantes et le comparer avec les pratiques d'il y a dix ans. Nous avons fondé le travail actuel sur l'enquête de Breitkreutz, Derwing, et Rossiter (2001) adressée aux enseignants et portant sur les ressources, les approches et les croyances relatives à l'enseignement de la prononciation. Dans l'ensemble, l'enseignement de la prononciation n'a pas changé de façon significative au cours des dix dernières années. Même s'il existe beaucoup plus d'occasions de formation, plusieurs des répondants estiment que ce n'est pas suffisant. Le nombre de cours de prononciation offerts dans le cadre des programmes d'ALS a également augmenté. Les croyances des enseignants par rapport à l'enseignement de la prononciation sont demeurées en grande partie les mêmes, mettant l'accent sur la production segmentaire et suprasegmentaire. Nous avons, toutefois, repéré une légère différence dans la façon dont les enseignants abordaient ces deux as- 
pects de la prononciation. Il y a 10 ans, les enseignants ont indiqué qu'ils portaient leur attention sur les deux aspects alors que de nos jours, on semble insister un peu plus sur la production segmentaire. Nous terminons en offrant plusieurs recommandations relatives aux programmes d'enseignement de l'ALS, aux programmes d'ALS et aux enseignants en ALS.

Ten years ago, Breitkreutz, Derwing, and Rossiter (2001) conducted a survey to determine the nature and extent of pronunciation instruction in English-as-asecond-language (ESL) classrooms in Canada. The era of communicative language teaching (CLT) had marked a "fall from grace" for pronunciation instruction (Isaacs, 2009, p. 2). Not only had CLT encouraged the belief that learners could improve their pronunciation through input alone (Breitkreutz et al.; Isaacs), but studies such as that of Purcell and Suter (1980) suggested that teaching pronunciation was ineffective. However, as the importance of pronunciation became clear to practitioner/researchers (Morley, 1991) and the noticing principle for second-language learning was increasingly accepted (Schmidt, 1990), some researchers began to focus on the possibility that teaching pronunciation could have an effect on overall intelligibility (understandability) of accented speech, as well as on comprehensibility (the effort required of a listener to understand accented speech, Derwing, Munro, \& Wiebe, 1997, 1998). Although this argument had been made in earlier eras (Abercrombie, 1949), there was little empirical evidence to sustain support for pronunciation instruction. Furthermore, during the 1990s, many new resources became available for both ESL teachers and learners (Celce-Murcia, Brinton, \& Goodwin, 1996; Dauer, 1992), which made it easier for ESL teachers to find pronunciation activities to incorporate into their classes. Breitkreutz et al. sought to determine "to what extent the recent renewal in interest in pronunciation that is reflected in research and teacher resource books is also evident in classroom practice" (p. 51). They found that although some instructors were indeed teaching pronunciation, many also expressed a desire for more training and better materials. Although today pronunciation instruction continues to be underrepresented in secondlanguage acquisition (SLA) research (Deng et al., 2009), several studies have been published since Breitkreutz et al.'s research that have furthered our understanding of adult second-language (L2) learners' pronunciation issues (Couper, 2003, 2006; Field, 2005; Hahn, 2004; Munro \& Derwing, 2006; Zielinski, 2006). Resources for stand-alone courses in pronunciation have flourished, with new editions and new entries (Dale \& Poms, 2005; Gilbert, 2005; Grant, 2010; Hewings, 2004) Furthermore, a survey of current teaching materials indicates that publishers now incorporate more pronunciation activities into their general-skills textbooks than previously (Derwing, Diepenbroek, \& Foote, in press). In the light of these developments, we determined that it was time to survey Canada's ESL instructors to find out if significant changes have occurred in ESL pronunciation teaching practices in the last decade. 
Breitkreutz et al. (2001) surveyed 67 instructors and/or program coordinators, most of whom were from Alberta, British Columbia, or Ontario. The goal of the research was to uncover to what extent pronunciation instruction was being incorporated into curricula and which approaches and materials were being used. Respondents' attitudes toward, and beliefs about, teaching and learning L2 pronunciation were also probed. They found that many instructors expressed a desire for training in how to teach pronunciation. Most respondents favored a mixture of segmental instruction (i.e., individual sounds such as $/ \mathrm{p} /$ and $/ \mathrm{b} /$ ) and suprasegmental instruction (i.e., broader aspects of pronunciation such as stress and intonation). The respondents also indicated a need for more materials and pronunciation-related curriculum development.

Although the study described above is the only Canadian survey of pronunciation-teaching practices of which we are aware, similar studies have been conducted in other English-speaking countries. Burgess and Spencer (2000) surveyed instructors in the United Kingdom to discover their teaching practices and attitudes toward teaching pronunciation. They found that although instructors recognized the importance of suprasegmentals, they found them difficult to teach. Some instructors also indicated that their learners had difficulty perceiving sounds that were not in their first language (L1). Finally, the results indicated that most instructors reported integrating pronunciation instruction into their classes rather than providing stand-alone pronunciation lessons. MacDonald (2002) conducted interviews with eight instructors in the Adult Migrant English Program (AMEP), a large, federally funded ESL program similar to LINC that focuses on pronunciation teaching practices and views. The results indicated a need for better materials and a stronger curriculum to support pronunciation teaching. Further, the study found that assessing and monitoring pronunciation were both problematic for instructors. Finally, Burns (2006) conducted a study in Australia with instructors in the AMEP. The survey inquired about instructors' teaching experience and their confidence levels in teaching pronunciation, as well as the materials and approaches that they favored. Burns found that instructors preferred the teaching of segmentals over suprasegmentals. In addition, her findings indicated that although instructors were fairly confident in their abilities, many desired more professional development in teaching pronunciation.

Although pronunciation does not receive as much academic attention as other aspects of SLA (Deng et al., 2009), it is of great concern to many L2 learners in Canada. Derwing and Rossiter (2002) surveyed 100 adult ESLlearners to learn about their pronunciation difficulties and strategies. Over $50 \%$ of the learners reported that pronunciation contributed to breakdowns in communication. Although it has been argued that L2-speakers may wish to maintain their accents as part of their identities (Golombek \& Rehn Jordan, 2005), Derwing (2003) found that 95\% of L2 immigrant respondents in- 
dicated that they would choose to speak like native speakers (NSs) if they could. Approximately a third of these same respondents stated that they had experienced some discrimination due to their accents, and 53\% felt that "Canadians would respect them more" if their pronunciation were better (p. 555). Other studies have also shown that foreign-accent discrimination is a problem faced by many L2-speakers in North America (Lippi-Green, 1997; Munro, 2003). In fact, Davila, Bohara, and Saenz (1993) and Reitz and Sklar (1997) demonstrated that an L2 accent is associated with an economic penalty for some individuals.

Although many ESL learners may wish to speak like NSs, the reality is that most people who learn a second language as adults will retain some degree of a foreign accent (Abrahamsson \& Hyltenstam, 2009; Flege, Munro, \& MacKay, 1995). Some researchers believe that it is possible for adults to achieve native-like speech (Bongaerts, Summeren, Planken, \& Schils, 1997). However, studies in support of the claim that adult learners of English can pass as native speakers are limited to research about people whose L1 is closely related to their L2 (Bongaerts et al.) or people who have had extensive interaction in their L2 through marriage (Piller, 2002).

Although pronunciation instruction is unlikely to lead to native-like speech, it can help L2 speakers improve their intelligibility. Research on the effectiveness of pronunciation instruction is limited, but some studies have demonstrated that instruction can make a positive difference. Derwing et al. (1997) conducted an experiment in which 12 weeks of pronunciation instruction were provided to $13 \mathrm{~L} 2$ speakers who had been living in Canada for between two and 20 years (with a mean length of residence of 10 years). The instruction focused much more heavily on prosodic features than on segmentals. The learners recorded speech samples at the start and end of the course; these samples were then rated by listeners for accentedness and comprehensibility and transcribed to measure intelligibility. The researchers found that of the 13 speakers, eight showed significant improvement on at least one of the measures of pronunciation. Couper (2003) gave pre- and posttests to 15 learners who received pronunciation instruction (focusing on both segmental and suprasegmental features) for approximately two hours per week for 16 weeks as part of an ESL course. He too found that the learners' pronunciation had improved. Three years later, Couper (2006) conducted a study focusing on epenthesis (inserting an extra sound) and absence (dropping a sound) in L2-learners' speech. He found that after receiving two weeks of special pronunciation instruction interspersed with regular English classes, learners made significant improvements. Finally, in a comparison of formfocused pronunciation instruction focusing on English $/ \lambda /$ with and without corrective feedback, Saito and Lyster (2011) determined that the group that received feedback improved, whereas the group that had no explicit correction did not. 
In the last two decades, there has been a shift from focusing primarily on segmentals to a greater emphasis on suprasegmentals in many pedagogical materials. Derwing et al. (1998) tested the effectiveness of three types on instruction on 48 ESL learners. The learners attended ESL classes for 20 hours per week for 12 weeks. One group received no pronunciation instruction, another received regular intervals of segmental training, and the third received regular intervals of suprasegmental training. Both groups receiving pronunciation instruction showed improvement when reading individual sentences aloud, but only the group that had suprasegmental instruction showed improvement when speaking extemporaneously. Hahn (2004) investigated the role of primary stress (sentence stress) on intelligibility. NS participants listened to one of three lectures given by a NNS. In one lecture, the speaker used appropriate primary stress, in another incorrect primary stress, and in the third no primary stress. Hahn found that listeners both retained more information and evaluated the speaker more highly when listening to the utterances with appropriate sentence stress. She concluded that sentence-level stress is important to ESL learners' intelligibility. Field (2005) investigated the role of lexical (word-level) stress on pronunciation and found that incorrect placement of lexical stress had a negative effect on intelligibility.

The increasing evidence that suprasegmental instruction is effective does not suggest that segmental instruction has no place in a pronunciation curriculum. However, given the limited class time usually allocated to pronunciation instruction, it is important to know which sounds should receive the most attention (Munro \& Derwing, 2006). One of the most common activities used to practice segmental distinctions is minimal pairs, words that differ by only one sound such as bug/rug or hat/hate. However, in an examination of minimal pairs commonly used in textbooks, Levis and Cortes (2008) found that in half of the minimal pairs that they examined, either one or both of the words was rarely used in speech. This does not mean that minimal pairs should not be used, but rather that they should be selected carefully. A concept that is useful in determining which sounds to teach is that of functional load (FL, Catford, 1987). A phoneme with a high FL is more likely to be important in distinguishing between two words than one with a low FL. Munro and Derwing examined the effects of high and low FL errors on the comprehensibility and accentedness of Cantonese speakers of English. They found that sentences with high FL errors were rated as more accented and less comprehensible by NSs of English.

Given the research findings over the past 10 years, we now address the following questions.

1. What pedagogical training in pronunciation do ESL instructors in Canada have or have access to?

2. How much, how, and with which materials is pronunciation being taught? 
3. What are instructors' beliefs and attitudes toward pronunciation instruction? In answering these questions, we determine whether pronunciation instruction in Canada has changed markedly in the last decade.

\section{Method}

\section{The Survey}

The survey was based on Breitkreutz et al.'s (2001) study with some changes and additions. It contained 45 questions that elicited information on several topics including: background information on participants and ESL programs (including classes and students), training opportunities available, resources and activities used, the nature and amount of pronunciation instruction taught, and beliefs about pronunciation instruction. The sections that dealt with materials and approaches were separated based on whether pronunciation was taught in stand-alone classes or integrated into general ESL classes; respondents answered applicable section(s). The section that dealt with beliefs about teaching pronunciation was required of all participants. Multiplechoice questions, yes/no questions, checklists, Likert scales, and open-ended questions were included in the survey, which was piloted by two ESL instructors. The survey took approximately 20-25 minutes to complete and was delivered using an online Web tool SurveyMonkey (2011, for a copy of the entire survey, please contact one of the authors).

\section{Participants}

In total, 201 individuals responded to the survey. However, because some people abandoned the questionnaire after completing only the first section (demographic information), each response form was manually checked and those including few answers were removed from the data set, leaving a total of 159. At a minimum, instructors needed to answer the short school demographic information section and at least one of the pedagogical sections: either the stand-alone, integrated or "all teachers" section. Generally, the instructors whose responses we analyzed had answered all the questions, leaving only the stand-alone section blank if it did not apply to them. We included responses from program directors although several questions were left unanswered (i.e., many of the teaching questions did not apply to them). Most of the respondents were instructors $(n=129,85 \%)$, whereas the rest were either program coordinators $(n=13)$ or both $(n=9)$. A few fell into other categories such as assessor or team lead. We received responses from eight provinces, but over $80 \%$ were from Alberta, British Columbia, and Ontario, the three provinces that receive the largest numbers of ESL newcomers (see Table 1).

The breakdown of participants between provinces differed from the earlier survey and was also not perfectly representative of immigration patterns in Canada. For example, fewer respondents were from Ontario and British Columbia than from Alberta although the former provinces receive more immigrants. 
Table 1

Percentage of Respondents from Provinces

\begin{tabular}{lcc}
\hline Province & Current Study (\%) & Previous Study (\%) \\
\hline Alberta & 33 & 21 \\
British Columbia & 24 & 31 \\
Ontario & 27 & 42 \\
Nova Scotia & 7 & - \\
Manitoba & 4 & - \\
Saskatchewan & 3 & - \\
New Brunswick & 0.7 & - \\
Quebec & 0.7 & - \\
Other & - & 5 \\
\hline
\end{tabular}

Most of the participants in the current study were in their 40 s or $50 \mathrm{~s}(63 \%)$, with $16 \%$ over the age of 60 and $21 \%$ under the age of 40 ; most were female $(89 \%)$. Twenty-eight respondents reported a first language other than English; the others were native English-speakers. Almost half of the respondents $(48 \%)$ had been teaching for 10 years or less. The others were divided fairly equally among the following categories: $10-15$ years $(20 \%), 15-20$ years $(16 \%)$, and more than 20 years (16\%). In terms of TESL preparation, almost half $(49 \%)$ held a TESL diploma from a college or university, whereas fewer than a quarter $(21 \%)$ held a master's in TESL. One person held a PhD in TESL, and $4 \%$ had a BEd in TESL (see Table 2).

Table 2

TESL Training Levels in Alberta, British Columbia, and Ontario

\begin{tabular}{lcccc}
\hline & & & & All \\
& $A B(\%)$ & $B C(\%)$ & ON (\%) & Provinces (\%) \\
\hline No formal TESL preparation & 19 & 0 & 6 & 10 \\
A non-credit TESL certificate & 19 & 10 & 17 & 16 \\
TESL Diploma from a college & 40 & 71 & 51 & 49 \\
or university & 5 & 0 & 3 & 4 \\
BEd in TESL & 17 & 19 & 20 & 21 \\
MEd/MA in TESL or applied linguistics & 0 & 0 & 3 & 1 \\
PhD in TESL or applied linguistics & & & & \\
\hline
\end{tabular}


Because our sample population was not completely representative of immigration patterns in Canada, we also compared the education levels of respondents from Ontario, Alberta, and British Columbia to see if there were major differences. We found that whereas respondents from Ontario generally had higher overall levels of TESL education, respondents from British Columbia and Alberta were more likely to have received high levels of pronunciation-specific training such as a credit course focused specifically on pronunciation instruction (see Table 3).

\section{Procedure}

First, we approached provincial ESL organizations across Canada and asked them to distribute the survey to their members. In some provinces, potential participants were then sent an e-mail request explaining the purpose of the study, the participants' rights, and the procedures. How, when, and whether the TESL organizations chose to share the information with their members is reflected in the response rates. Some organizations made it easier for their members to respond than did others. For example, some provided a direct link, and others required their members to go to another Web site. Some distributed the information right away in spring 2010, whereas others waited until after approval was obtained at a board meeting and sent the information in the summer when fewer respondents were at work. In some provinces, we received no response from the professional organizations; in these instances, we approached programs directly and re-

Table 3

Pronunciation-Specific Training in Alberta, British Columbia, and Ontario*

\begin{tabular}{|c|c|c|c|c|}
\hline & $A B(\%)$ & $B C(\%)$ & ON (\%) & $\begin{array}{c}\text { All } \\
\text { Provinces (\%) }\end{array}$ \\
\hline None & 4 & 3 & 14 & 5 \\
\hline Sporadic workshops at conferences & 67 & 71 & 68 & 66 \\
\hline $\begin{array}{l}\text { As part of a general TESL or } \\
\text { linguistics course }\end{array}$ & 51 & 74 & 54 & 59 \\
\hline Linguistics courses & 53 & 68 & 38 & 52 \\
\hline $\begin{array}{l}\text { A credit course that focuses specifically } \\
\text { on pronunciation teaching }\end{array}$ & 22 & 26 & 14 & 20 \\
\hline $\begin{array}{l}\text { A combination of linguistics courses } \\
\text { and a pedagogical pronunciation course }\end{array}$ & 20 & 23 & 14 & 18 \\
\hline
\end{tabular}

${ }^{*}$ Respondents were able to check more than one answer. 
quested that the introductory letter be distributed to ESL teachers on staff. SurveyMonkey provided counts for responses on closed questions; for open-ended questions, each response was coded, entered into a spreadsheet, counted, and double-checked.

\section{Results}

\section{Background Information}

Most of the participants taught in large programs: $37 \%$ were from programs with $11-20$ classes and $27 \%$ from programs with more than 20 classes. When asked to describe their students using a checklist, the respondents indicated that most were immigrants (81\%) and federally funded (67\%). Other students (with a higher than $30 \%$ response rate) included: exam-prep (IELTS, TOEFL), non-federally funded students (e.g., provincially funded), fee-paying, academic bridging, occupation-specific (e.g., internationally trained nurses), refugees, and international students. Most of the respondents taught at levels between CLB 3 and CLB 6, although all the levels from literacy to CLB 10 were reported. The highest percentage reported teaching CLB 4 and CLB 5. A large number of respondents $(85 \%)$ indicated that they had students who had requested pronunciation instruction or classes. Of the approximately 40 languages that the respondents suggested were challenging for English pronunciation, eight were mentioned 10 or more times (see Table 4).

Six of the eight languages listed are from Asian countries; this could reflect the large number of Asian students in Canadian ESL classes.

Table 4

Most Troublesome Languages, in Terms of Pronunciation

\begin{tabular}{lc}
\hline Language & Mentions \\
\hline Chinese* $^{*}$ & 98 \\
Vietnamese & 61 \\
Spanish & 28 \\
Korean & 27 \\
"Asian" & 23 \\
Japanese & 12 \\
Arabic & 10 \\
Thai & 10 \\
\hline
\end{tabular}

*The terms Chinese, Mandarin, and Cantonese were used by the respondents. We collapsed them into Chinese. 


\section{Pedagogical Training}

Fifty percent of respondents indicated that some of the instructors in their institutions had special training in pronunciation, $18 \%$ indicated that none did, and 32\% were unsure. Respondents were also asked to indicate what types of pronunciation training they themselves had received; most had received sporadic pronunciation professional development at conference presentations or workshops (66\%). Fifty-nine percent had received instruction as part of a general TESL or linguistics course, $52 \%$ had taken linguistics courses such as phonetics or phonology, and $20 \%$ had taken a credit course at university that specifically focused on L2 pronunciation instruction. In terms of accessibility, most (81\%) indicated that instructors could access conference presentations, over a third (38\%) said that they were able to attend in-house seminars or workshops, and $18 \%$ indicated that they could take commercial courses offered by private businesses. Just over half (51\%) indicated that instructors could access college or university courses that focused on the teaching of pronunciation.

\section{Approaches and Materials}

Integrating pronunciation into general ESL classes. The respondents were relatively positive about whether most instructors at their institutions were able to integrate pronunciation instruction into their classes, with $70 \%$ reporting that they could. Only $12 \%$ said that they could not, and $18 \%$ were unsure. However, can and do are not the same, and fewer than half (46\%) of the respondents agreed that the instructors at their institution incorporated pronunciation into their regular classes. A third (36\%) were not sure what their colleagues did, and $18 \%$ said that their colleagues did not incorporate pronunciation. When reporting on their own practices, teachers indicated that they regularly integrated pronunciation into their general ESL classes (86\%) and that they regularly corrected mispronunciations (73\%). As for the amount of time spent on pronunciation instruction, a percentage was calculated for each teacher when possible. Respondents were asked to provide the total number of teaching hours per week and then select the amount of time spent on pronunciation from a list (less than 15 minutes, 15 minutes, 30 minutes, 60 minutes, 90 minutes, 120 minutes, and more than 120 minutes). We were unable to calculate exact percentages when respondents selected less than 15 minutes or more than 120 minutes, but we determined rough percentages to gain an idea of time spent on pronunciation. First, we examined only those responses that had exact numbers $(n=99)$. We then determined the ranges and means for the total number of instructional hours per week, the total number of hours spent on pronunciation, and the percentage of class time per week devoted to pronunciation instruction. The 99 teachers in this subset taught an average of 17.13 hours per week (Range=2-35 hrs/week). Less than one hour on average was spent on pronunciation $(M=0.86$, 
Range $=0.25-2$ hours $/$ week). Teachers generally spent a mean of about $6 \%$ of their weekly class time on pronunciation instruction (Range $=1-25 \%$ ). However, the median response was lower, at $5 \%$, and the mode response was only $2 \%$.

Just over half the respondents (52\%) reported that they used the pronunciation activities in their general skills textbooks. Twenty-nine texts were mentioned: Side by Side (Molinsky \& Bliss, 2002) was mentioned five times, and Canadian Snapshots (Angst, Davis, Bertram, \& Bonkowski, 2005) three times. The rest were mentioned only once or twice. Teachers were also asked if they used any pronunciation-specific textbooks in their classes. Just over half $(56 \%)$ reported that they did, and 40 texts were mentioned. Clear Speech (Gilbert, 2005) was by far the most popular, mentioned 30 times, followed by Pronunciation Pairs (Baker \& Goldstein, 2008) 15 times, and Well Said (Grant, 2010) 11 times. The rest of the texts were mentioned between once and five times. Fifty-nine percent of teachers responded Yes to the question about using pronunciation texts to supplement their classes. Clear Speech (Gilbert) appeared to be more popular when used as a student course textbook: it was mentioned only seven times as a supplementary resource for instructors, although it was still among the most popular. Teaching American English Pronunciation (Avery \& Ehrlich, 1992) and Teaching Pronunciation (Celce-Murcia et al., 1996) were mentioned most frequently, eight times each. Pronunciation Pairs (Baker \& Goldstein), Pronunciation Practice Activities (Hewings, 2004), and Pronunciation Games (Hancock, 1996) were each mentioned four times; the remainder were mentioned once to three times. A number of online resources were also cited, but no single online site was popular.

Stand-alone pronunciation classes. When asked if their institutions offered stand-alone pronunciation classes, $43 \%$ answered affirmatively. According to the respondents, students were placed in stand-alone pronunciation

\section{Table 5}

Most Serious Pronunciation Problems Experienced by Students in Stand-Alone Classes

\section{Pronunciation Problem}

Number of Mentions

Intonation

Word/syllable endings

Word/syllable stress

Vowels

$\begin{array}{ll}\text { Specific consonants (e.g., p, b) } & 18\end{array}$

Sentence stress/phrasing

Rhythm

Stress (type not specified) 
classes according to self-identification (64\%) or teacher recommendation $(55 \%)$. Teachers cited many pronunciation problems experienced by their students (see Table 5 for those mentioned more than 10 times).

Generally, stand-alone pronunciation teachers employed more pronunciation resources than did regular ESL teachers. Some instructors reported using pronunciation activities in regular ESL textbooks as part of their stand-alone classes. Of these, the most common were Side by Side (Molinsky \& Bliss, 2002), Focus on Grammar (Schoenberg \& Maurer, 2006), Canadian Concepts (Berish \& Thibaudeau, 1997), and Canadian Snapshots (Angst et al., 2005), with each being mentioned three to four times. In terms of pronunciation textbooks used in classes (vs. supplements), Clear Speech (Gilbert, 2005), Pronunciation Pairs (Baker \& Goldstein, 2008), and Well Said (Grant, 2010) were again the most popular with 27, 17, and 13 mentions respectively. Instructors reported using approximately 90 types of resources overall, including Web resources and online tools, textbooks, resource books, and so forth.

Pronunciation assessment in stand-alone pronunciation classes varied extensively. The 82 respondents who answered the question We assess students' improvement in pronunciation by: mentioned close to 40 ways to assess pronunciation. The most popular of these included in-class performance/observation, using pre- and post-recordings of speech, tests, and peer evaluations. Several instructors also indicated that they did not assess pronunciation progress.

The structure of stand-alone classes also varied. Reported class lengths ranged from 10 minutes to three hours, and the descriptions offered by respondents about the organization of their classes differed so much that it was impossible to make generalizations; many reported using a variety of activities and focusing on a wide array of pronunciation issues, whereas others seemed to focus more closely on one or two types of problems (e.g., vowels).

We also asked instructors of stand-alone classes what was most difficult about teaching pronunciation. Seventy-one responded and mentioned many challenges. The most common problem (22 instances) was finding aspects on which to focus that applied to all students in the class, especially when the learners were from varied language backgrounds. Making the class interesting for learners and preventing learners' boredom was the second most common problem (14 instances). Teaching multi-level groups was another common complaint (11 instances). Some instructors expressed frustration over lack of student motivation, when learners did not see the benefit of pronunciation instruction (4 instances), as well as lack of time (4 instances), especially for one-on-one instruction (5 instances), and resources (4 instances).

General approaches to teaching pronunciation. The respondents were first asked which activities were the most effective for improving students' pronunciation. Among the wide range of responses, five popular activities were using minimal pairs (e.g., BINGO or telephone), employing repetition (in- 
cluding some modeling and/or correction), using mirrors, having students record and listen to themselves, and using diagrams of the mouth to explain correct articulation and having students feel where/how they were speaking. Intonation was also mentioned frequently, but not always with a clear activity used to teach it. We categorized all the activities as being primarily segmental (e.g., minimal pairs), primarily suprasegmental (e.g., marking a passage for intonation), a mixture of both (e.g., repetition), or other (e.g., working one on one). Segmental activities were mentioned the most often (55 times), followed by suprasegemental activities (39 times), activities that emphasized both (26 times), and other (24 times).

Nearly all the participants reported spending at least some time on prosodic features, but $32 \%$ spent less than a third of their time on prosody. Twenty-six percent spent $40-60 \%$ of their time on prosodic features, and 33\% spent $70-90 \%$ of their time on prosody. Nine percent reported spending all their time on prosodic features.

We also asked instructors to describe the most difficult aspects of pronunciation to teach in a stand-alone pronunciation class. We categorized the 43 distinct answers as follows: segments, suprasegmentals, learner variables, L1 interference/accent, and miscellaneous. Segments and suprasegmentals were almost tied for the top response, with 55 respondents nominating segments and 54 mentioning suprasegmentals. The next most common answer type, with 27 instances, was learner variables such as breaking bad habits and lack of motivation. The next category, L1 interference/accent, was mentioned 20 times. This category covered a wide range of general suggestions that could have an effect on teaching pronunciation, including answers such as accent. The miscellaneous category had 14 respondents and contained suggestions such as paraphrase, long words, and British vowels.

Finally, teachers were asked to report which strategies they recommended to students in instances of communication breakdown. The respondents selected all that applied from a checklist, but they could also write in their own strategies in an Other field. Repetition was the most popular strategy $(81 \%)$, followed by focus on troublesome sounds $(63 \%)$, speak slower $(62 \%)$, paraphrase (61\%), and spell the word (51\%). Only six\% selected speak faster as an option.

\section{Beliefs and Attitudes}

We asked the teachers to respond to a series of statements to gauge their attitudes toward, and beliefs about, pronunciation instruction (see Table 6). The participants indicated their agreement with the statements on a sevenpoint scale, which we then collapsed into three categories: agree, neutral, and disagree. The respondents were generally positive about teaching pronunciation. Most (73\%) did not think that teaching pronunciation was boring, and only $23 \%$ believed that pronunciation instruction did not result in permanent 
changes. Most of the participants (85\%) also recognized that pronunciation instruction could be effective even if learners had been living in Canada for more than two or three years. Although generally positive, many instructors were not confident in their abilities to teach pronunciation; only $58 \%$ agreed that they were completely confident teaching segmentals, and even fewer were comfortable teaching prosodic features (56\%). Further, fully $75 \%$ wished that they had more training in teaching pronunciation.

Table 6

Teachers' Beliefs about Pronunciation Instruction

\begin{tabular}{|c|c|c|c|}
\hline Statement & $\%$ Agree & $\%$ Neutral & $\%$ Disagree \\
\hline $\begin{array}{l}\text { Teaching pronunciation does not usually } \\
\text { result in permanent changes. }\end{array}$ & 23 & 15 & 62 \\
\hline $\begin{array}{l}\text { Drilling minimal pairs is the best way to } \\
\text { teach pronunciation. }\end{array}$ & 14 & 27 & 60 \\
\hline $\begin{array}{l}\text { Communicative practice is the best way } \\
\text { to teach pronunciation. }\end{array}$ & 55 & 26 & 18 \\
\hline $\begin{array}{l}\text { A heavy accent is a cause of discrimination } \\
\text { against ESL speakers. }\end{array}$ & 70 & 13 & 18 \\
\hline Teaching pronunciation is boring. & 18 & 8 & 73 \\
\hline $\begin{array}{l}\text { Pronunciation instruction is most effective } \\
\text { in a class with the same } L 1 \text {. }\end{array}$ & 35 & 10 & 54 \\
\hline $\begin{array}{l}\text { Pronunciation instruction is only effective in the } \\
\text { first two to three years after arrival. }\end{array}$ & 6 & 10 & 85 \\
\hline You can't teach pronunciation to lower levels. & 5 & 1 & 94 \\
\hline Only native speakers should teach pronunciation. & 28 & 15 & 57 \\
\hline $\begin{array}{l}\text { There is an age-related limitation on the } \\
\text { acquisition of native-like pronunciation. }\end{array}$ & 55 & 13 & 32 \\
\hline $\begin{array}{l}\text { Pronunciation instruction is only effective for } \\
\text { highly motivated learners. }\end{array}$ & 39 & 23 & 38 \\
\hline $\begin{array}{l}\text { Some individuals resist changing their pronunciation } \\
\text { in order to maintain their L1 identity. }\end{array}$ & 37 & 22 & 41 \\
\hline $\begin{array}{l}\text { Pronunciation teaching should help make students } \\
\text { comfortably intelligible to their listeners. }\end{array}$ & 89 & 5 & 6 \\
\hline $\begin{array}{l}\text { The goal of a pronunciation program should be to } \\
\text { eliminate, as much as possible, foreign accents. }\end{array}$ & 12 & 6 & 83 \\
\hline l'm completely comfortable teaching segmentals. & 58 & 20 & 22 \\
\hline $\begin{array}{l}\text { I'm completely comfortable teaching all aspects } \\
\text { of prosody (suprasegmentals). }\end{array}$ & 56 & 15 & 26 \\
\hline I wish I had more training in teaching pronunciation. & 75 & 10 & 15 \\
\hline
\end{tabular}


The respondents recognized the importance of pronunciation for their learners. Almost all (92\%) indicated that some learners in their institutions would benefit from a stand-alone pronunciation class. Pronunciation instruction was seen as important for learners at all levels, with $83 \%$ of respondents agreeing that it was important for beginners, 91\% agreeing that it was important for intermediate learners, and $86 \%$ agreeing that it was important for advanced learners. As well as being important at varying levels of proficiency, $82 \%$ believed that pronunciation instruction was important for people in certain occupations. When asked to indicate which professions most required pronunciation instruction, the top answers were medical/healthcarerelated (e.g., nursing) and jobs that demanded communication with the public and/or use of the telephone.

\section{Discussion}

Ten years on from the Breitkreutz et al. (2001) study, it is clear that although some areas of pronunciation instruction have changed, others have remained much the same.

\section{What pedagogical training in pronunciation do instructors have?}

In the original study, only $12 \%$ of respondents indicated that they could access college or university courses on teaching pronunciation. In the present study, this number increased to $51 \%$; however, after conducting a scan of the Web sites of all Canadian universities offering programs in TESL, it appears that only six universities offer pronunciation-specific courses. Of the 64 people who indicated that they could access a course, only 25 lived in or near cities where such a course exists. Some individuals may receive pertinent training as a component of a more generally titled course such as TESL Methodology, but it is clear that few universities devote a whole course to L2 pronunciation. This may help explain the provincial differences in instructors' levels of pronunciation-specific training. We suspect that some respondents may have overestimated the availability of teacher training for pronunciation. In terms of other types of professional development, 31\% fewer people in the current study indicated that they had access to in-house seminars, whereas access to conference presentations remained nearly identical at approximately $80 \%$ in both studies. Comparing the figures from the last study, the percentage of respondents who indicated that some of the instructors in their institutions had pronunciation training increased by $20 \%$ over the earlier study. However, it also appears that instructors may not be integrating pronunciation instruction into their classes as much as they did in the past. In the earlier study, $73 \%$ of respondents said that instructors in their programs taught pronunciation, but in the current study, only $46 \%$ said that most instructors in their institutions incorporated pronunciation instruction into their classes. Although $86 \%$ of respondents in the current study said 
that they themselves tried to incorporate pronunciation regularly, this number is probably not representative of ESL instructors in general. Participants selfselected to take the survey, and it is reasonable to assume that people who do not teach pronunciation at all would be less inclined to take the survey.

Based on the data from the two surveys, it seems that although there may be somewhat increased training opportunities, instructors are still not receiving the professional development they need to feel completely comfortable teaching pronunciation. In the 2001 study, many respondents had indicated that they wanted more professional development opportunities. The demand for increased support has not faded; $75 \%$ of respondents in the present study indicated that they would like more pronunciation training. For example, respondents wrote, "Anything would be nice!" and "Very little is being done in this area. I often look for pronunciation workshops but don't find them," "Too many teachers avoid teaching pronunciation because they lack confidence in their own ability to succeed with it," and "I think many teachers are uncomfortable teaching pronunciation and tend to avoid it."

\section{How much, how, and with which materials is pronunciation being taught?}

As can be seen from the results, many instructors indicated that they regularly include pronunciation instruction in their regular classes and regularly correct pronunciation errors. However, as with the first study, it was unclear how often and which type of errors were most frequently corrected. It also appears that a relatively limited portion of class time is spent on pronunciation. When asked about the inclusion of pronunciation materials, only $56 \%$ of respondents acknowledged that they incorporated pronunciation texts in addition to their regular ESL textbooks. A slightly lower percentage of respondents stated that their programs offered stand-alone classes ( $43 \%$ compared with $46 \%$ in the earlier study).

How instructors approach pronunciation instruction in the classroom varies extensively. Interestingly, although respondents generally seemed to be aware of the importance of suprasegmentals, most of the activities mentioned when instructors were asked to describe which activities "helped students the most" were those that targeted segmental problems such as minimal pairs. Nonetheless, it does seem that overall, awareness of prosodic features is increasing. For example, in the earlier study, when respondents were asked to indicate which aspects of pronunciation they found the most difficult to teach, $64 \%$ chose segmental difficulties. In the current study, there was a fairly even split between segmental and prosodic issues. Further, as seen in Table 5, many of the pronunciation problems that instructors identified as being most serious were prosodic in nature.

The strategies chosen for dealing with communication breakdowns varied from the earlier study, but not dramatically. The most popular strategy se- 
lected in the current study was repetition; in the earlier study the most frequent response was focusing on troublesome sounds. One interesting difference was that speaking more slowly was chosen as a recommended strategy by $42 \%$ of respondents in the first study, but by $62 \%$ in the current study; this is a strategy that should be used with caution. As Munro and Derwing (1998) have shown, slowing down is not always appropriate, and in fact some students need to increase their rate to improve their comprehensibility (a strategy recommended by only $6 \%$ of respondents).

Pronunciation assessment in Canada has not changed radically in the past 10 years. In the first survey, instructors listed a wide range of activities including several that were near the top of the list in the current study such as pre- and post-recordings, informal assessment, and tests. One interesting finding from the current study was that some instructors did not have an assessment in place in pronunciation classes.

It is to be expected that over the course of a decade, new pronunciation materials and resources will have been developed to replace some of those mentioned in the earlier study. This has happened, but the top three resources mentioned in the current study were also in the top 10 of the earlier study (all three are now in later editions). Of those three, one focuses on segmentals (Pronunciation Pairs), one on suprasegmentals (Well Said), and one focuses on both (Clear Speech).

\section{What are instructors' beliefs and attitudes toward pronunciation instruction?}

This question revealed a generally positive attitude toward pronunciation instruction. A large percentage of instructors believed that there were learners in their schools who would benefit from a stand-alone pronunciation class; most saw pronunciation instruction as important at all levels of proficiency. Instructors also made comments suggesting that not enough was being done to help learners with pronunciation such as "We could be doing far more[pronunciation] gets overlooked far too often!" However, it should be mentioned that there were also indications that not all instructors viewed pronunciation as important. For example, one person wrote, "Pronunciation doesn't have the same importance as L/S, grammar, reading, and writing," and another said, "I have found that other instructors feel unprepared to teach pronunciation and some don't see it as valuable."

Generally speaking, the attitudes toward pronunciation instruction shown in Table 6 are not much different from those of the first study and are in keeping with other research findings (Burns, 2006). However, some differences emerged. Respondents in the current study were slightly more pessimistic about the ability of pronunciation instruction to create permanent changes, with 5\% more thinking that it did not. In the earlier study, in response to the statement "Some individuals resist changing their pronunciation to maintain 
their L1 identity," 35\% agreed, 9\% were unsure, and 56\% disagreed. In the current study, people were more open to this notion with $37 \%$ agreeing, $22 \%$ being unsure, and $41 \%$ disagreeing. This is an interesting finding in the light of Derwing's (2003) findings, which showed that most immigrant L2 learners would prefer to speak like NSs.

Through the respondents' answers to this survey, we were able to gain insights into their strengths and weaknesses, their successes and challenges. With this knowledge, we present recommendations for TESL programs, English-language programs, and ESL teachers.

\section{Recommendations}

\section{TESL Programs}

Given that only $20 \%$ of the respondents reported taking an entire course specifically focused on teaching pronunciation, as opposed to a linguistics course or a unit within a general TESL course, more TESL programs should offer pedagogical courses on the teaching of pronunciation. Currently, only six master's programs in Canada offer a dedicated course in teaching pronunciation. Teachers should have access to more than just conference presentations and workshops for training in this area.

\section{English-Language Programs}

ESL programs should encourage their teachers to take advantage of reputable professional development opportunities in teaching pronunciation. Based on some teachers' comments, it is evident that teachers would benefit from such courses. In addition, we recommend that larger ESL programs offer standalone pronunciation courses. Given that $85 \%$ of teachers reported having students who requested pronunciation courses and that $92 \%$ agreed that they had had students who would benefit from a stand-alone pronunciation class, it appears that the supply is not meeting the demand. When asked if their programs offered stand-alone pronunciation classes, more than half the participants $(54 \%)$ responded that they did not, and three percent were unsure.

Finally, we recommend that all teachers consistently integrate pronunciation into their general ESL classes. Although $86 \%$ of teachers reported that they regularly integrated pronunciation into their classes, only $46 \%$ were confident that most their colleagues were doing so. Furthermore, 73\% said that they regularly corrected mispronounced words. It is conceivable that this non-systematic approach is the only pronunciation instruction that many students receive. Furthermore, many teachers reported spending less than $5 \%$ of their class time on pronunciation; in fact some teachers spent as little as $1 \%$ of their time on pronunciation instruction. We suggest that teachers first try to identify their learners' problems, especially problems that many learners share. This will make it easier to incorporate systematic activities and feedback into unit and lesson planning. For example, if learners have 
trouble with the pronunciation of numbers, an instructor could include a lesson on word stress placement in words such as thirty/thirteen in a lesson focusing on count/non-count nouns or telling time. Pronunciation features should be cycled; learners need reinforcement if they are to make a permanent change to an aspect of their pronunciation.

\section{Teachers}

For teachers, we have two recommendations, keeping in mind that intelligibility should be the primary goal of pronunciation instruction. This goal was reflected in teachers' beliefs, with most agreeing to some extent and almost half $(43 \%)$ strongly agreeing. In addition, most respondents disagreed with the idea that the purpose of pronunciation instruction should be to eliminate foreign accents. Still, it is important to keep this principle in mind when teaching pronunciation.

The first recommendation is to provide explicit feedback to students on both segmental and suprasegmental problems. As mentioned above, $73 \%$ reported that they regularly corrected mispronounced words; unfortunately, the extent to which prosodic features were corrected in class was not clear. The correction of suprasegmentals is probably not as frequent as the correction of segmentals because the former are less salient and more difficult in terms of immediate feedback. Because the suprasegmental aspects of pronunciation are important to intelligibility (Hahn, 2004; Munro \& Derwing, 1995), it is essential that teachers ensure that they correct prosodic errors along with individual words.

Our second suggestion is that teachers first focus on the problems that have the highest effect before moving on to other features. For example, sentence stress has been shown to have a significant effect on comprehensibility and intelligibility (Hahn, 2004), yet in the current study many teachers' favored activities that focused on individual sounds, and even those sounds may not have been the optimal choices for segments. Catford (1987) developed a hierarchical list of those sounds that affected intelligibility the most, which can help instructors make informed decisions about segmental instruction.

Finally, because respondents reported using such a wide range of resources, some less than ideal, we would suggest some starting points for instructors. Teaching Pronunciation (Celce-Murcia, Brinton, Goodwin, \& Griner, 2010) and Teaching Pronunciation: A Handbook for Teachers and Trainers (Fraser, 2001) are two texts designed for teachers that offer good information on approaches and strategies for teaching pronunciation. Give it a Go: Teaching Pronunciation to Adults (Yates \& Zielinski, 2009) is a useful online resource that also presents principles for teaching pronunciation. When choosing pronunciation materials to use in class, teachers should use critical judgment. It is important to be wary of "segmental-heavy" resources; often pronunciation textbooks focus only on consonants and vowels. A good pronunciation 
textbook should have a balance between practice on individual sounds and work on prosodic variables. There is little purpose in having students practice isolated phrases because intonation and stress are better understood in context. To combat students' boredom, it is advisable to avoid texts that rely on drills; texts that have interactive activities that are easily teachable are preferable. Clear Speech (Gilbert, 2005), Well Said (Grant, 2010), and Sound Concepts (Reed \& Michaud, 2005) are examples of good resources that teachers can use in class with students. Although they require more work on the part of the teacher, examples of relatively authentic language use from TV, films, YouTube, and radio can be used in innovative ways to teach pronunciation.

\section{Conclusion}

In this research, we examined teachers' approaches to and beliefs about pronunciation instruction. We also explored differences from an earlier (2001) study to determine if there were any patterns of change. Generally, there were few differences in teachers' responses over the past 10 years. Teachers seem to understand the importance of pronunciation instruction. We hope that in the next 10 years more professional development opportunities will become available to help instructors integrate pronunciation into their teaching.

\section{Acknowledgments}

The authors thank the provincial professional associations and individual programs that helped us contact participants for this study. We are grateful to the many people who took time to complete the survey. Thanks also to Lori Diepenbroek and Bonnie Holtby for their assistance. Three anonymous reviewers provided us with useful feedback.

\section{The Authors}

Jennifer Foote (MEd TESL) is a doctoral student at Concordia University. She has also taught English in Canada, Japan, the Czech Republic, and South Korea. She is interested in issues related to teaching pronunciation.

Amy K. Holtby (MEd TESL) is currently teaching at the College of the North Atlantic in Qatar. She is a graduate of the University of Alberta TESL program where she also worked as a research assistant.

Tracey Derwing is a professor in the TESL program at the University of Alberta. She has conducted numerous studies examining pronunciation and oral fluency development in secondlanguage learners and their relationship to intelligibility, comprehensibility, and accent.

\section{References}

Abercrombie, D. (1949). Teaching pronunciation. ELT Journal, 3, 113-122.

Abrahamsson, N., \& Hyltenstam, K. (2009). Age of onset and nativelikeness in a second language: Listener perception versus linguistic scrutiny. Language Learning, 59, 249-306.

Angst, K., Davis, M.J., Bertram, C., \& Bonkowski, F. (2005). Canadian snapshots. Quebec, QC: Pearson Longman.

Avery, P., \& Ehrlich, S. (1992). Teaching American English pronunciation. New York: Oxford University Press. 
Baker, A., \& Goldstein, S. (2008). Pronunciation pairs (2nd ed.). New York: Cambridge University Press.

Berish, L., \& Thibaudeau, S. (1997). Canadian concepts. Scarborough, ON: Prentice Hall.

Bongaerts, T., van Summeren, C., Planken, B., \& Schils, E. (1997). Age and ultimate attainment in the pronunciation of a foreign language. Studies in Second Language Acquisition, 19, 447-465.

Breitkreutz, J., Derwing, T.M., \& Rossiter, M.J. (2001). Pronunciation teaching practices in Canada. TESL Canada Journal, 19, 51-61.

Burgess, J., \& Spencer, S. (2000). Phonology and pronunciation in integrated language teaching and teacher education. System, 28, 191-215.

Burns, A. (2006). Integrating research and professional development on pronunciation teaching in a national adult ESL program. TESL Reporter, 39, 34-41.

Catford, J.C. (1987). Phonetics and the teaching of pronunciation: A systemic description of English phonology. In J. Morley (Ed.), Current perspectives on pronunciation (pp. 878-100). Washington, DC: TESOL.

Celce-Murcia, M., Brinton, D.M., \& Goodwin, J.M. (1996). Teaching pronunciation: A reference for teachers of English to speakers of other languages. Cambridge, UK: Cambridge University Press.

Celce-Murcia, M., Brinton, D.M., Goodwin, J.M., \& Griner, B. (2010). Teaching pronunciation: A course book and reference guide (2nd ed.). New York: Cambridge University Press.

Couper, G. (2003). The value of an explicit pronunciation syllabus in ESOL teaching. Prospect, 18, 53-70.

Couper, G. (2006). The short- and long-term effects of pronunciation instruction. Prospect, 21, 46-66.

Dale, P., \& Poms, L. (2005). English pronunciation made simple (2nd ed.). White Plains, NY: Longman.

Dauer, R.M. (1992, March). Teaching the pronunciation of connected speech. Paper presented at the meeting of TESOL, Vancouver, BC.

Davila, A., Bohara, A., \& Saenz, R. (1993). Accent penalties and the earnings of Mexican Americans. Social Science Quarterly, 74, 902-916.

Deng, J., Holtby, A., Howden-Weaver, L., Nessim, L., Nicholas, B., Nickle, K., Pannekoek, C., Stephan, S., \& Sun, M. (2009). English pronunciation research: The neglected orphan of second language acquisition studies? (WP 05-09). Edmonton, AB: Prairie Metropolis Centre.

Derwing, T.M. (2003). What do ESL students say about their accents? Canadian Modern Language Review, 59, 547-567.

Derwing, T.M., Diepenbrook, L., \& Foote, J. A. (in press). An examination of pronunciation, fluency, and pragmatics in ESL textbooks.

Derwing, T.M., Munro, M.J., \& Wiebe, G.E. (1997). Pronunciation instruction for "fossilized" learners: Can it help? Applied Language Learning, 8, 217-235.

Derwing, T.M., Munro, M.J., \& Wiebe, G.E. (1998). Evidence in favour of a broad framework for pronunciation instruction. Language Learning, 48, 393-410.

Derwing, T.M., \& Rossiter, M.J. (2002). ESL learners' perceptions of their pronunciation needs and strategies. System, 30, 155-166.

Field, J. (2005). Intelligibility and the listener: The role of lexical stress. TESOL Quarterly, 39, 399-423.

Flege, J.E., Munro, M.J., \& Mackay, I.R.A. (1995). Factors affecting degree of perceived foreign accent in a second language. Journal of the Accoustical Society of America, 97, 3125-3134.

Fraser, H. (2001). Teaching pronunciation: A handbook for teachers and trainers. Sydney, Australia: TAFE NSW Access Division. Available: http:/ / catalogue.nla.gov.au/Record/565346

Gilbert, J. (2005). Clear speech: Pronunciation and listening comprehension in American English (3rd ed.). New York: Cambridge University Press.

Grant, L. (2010). Well said (3rd ed.). Boston, MA: Heinle \& Heinle.

Golombek, P., \& Rehn-Jordan, S. (2005). Becoming "Black Lambs" not “Parrots": A poststructuralist orientation to intelligibility and identity. TESOL Quarterly, 39, 513-533. 
Hahn, L. (2004). Primary stress and intelligibility: Research to motivate the teaching of suprasegmentals. TESOL Quarterly, 38, 201-223.

Hancock, M. (1996). Pronunciation games. Cambridge, UK: Cambridge University Press.

Hewings, M. (2004). Pronunciation practice activities. Cambridge, UK: Cambridge University Press.

Isaacs, T. (2009). Integrating form and meaning in L2 pronunciation instruction. TESL Canada Journal, 27, 1-12.

Levis, J., \& Cortes, V. (2008). Minimal pairs in spoken corpora: Implications for pronunciation assessment and teaching. In C.A. Chapelle, Y.-R. Chung, \& J. Xu (Eds.), Towards adaptive CALL: Natural language processing for diagnostic assessment (pp. 197-208). Ames, IA: Iowa State University.

Lippi-Green, R. (1997). English with an accent: Language ideology and discrimination in the United States. New York: Routledge.

MacDonald, S. (2002). Pronunciation-Views and practices of reluctant teachers. Prospect, 17, 3-18.

Molinsky, S.J., \& Bliss, B. (2002). Side by side. White Plains, NY: Pearson Longman.

Morley, J. (1991). The pronunciation component of teaching English to speakers of other languages. TESOL Quarterly, 25, 481-520.

Munro, M.J. (2003). A primer on accent discrimination in the Canadian context. TESL Canada Journal, 20, 38-51.

Munro, M.J., \& Derwing, T.M. (1995). Foreign accent, comprehensibility, and intelligibility in the speech of second language learners. Language Learning, 45, 73-97.

Munro, M.J., \& Derwing, T.M. (1998). The effects of speaking rate on listener evaluations of native and foreign-accented speech. Language Learning, 48, 159-182.

Munro, M.J., \& Derwing, T.M. (2006). The functional load principle in ESL pronunciation Instruction: An exploratory study. System, 34, 520-531.

Piller, I. (2002). Passing for a native speaker: Identity and success in second language learning. Journal of Sociolinguistics, 6, 179-206.

Purcell, E.T., \& Suter, R.W. (1980). Predictors of pronunciation accuracy: A reexamination. Language Learning, 30, 271-287.

Reed, M., \& Michaud, C. (2005). Sound concepts: An integrated pronunciation course. New York: McGraw-Hill.

Reitz, J., \& Sklar, S. (1997). Culture, race, and the economic assimilation of immigrants. Sociological Forum, 12, 233-277.

Saito, K., \& Lyster, R. (2011). Effects of form-focused instruction and corrective feedback on L2 pronunciation development of / $/$ / by Japanese learners of English. Language Learning, Advance online publication: doi: 10.1111/j.1467-9922.2011.00639.x

Schmidt, R. (1990). The role of consciousness in second language learning. Applied Linguistics, 11, 129-158.

Schoenberg, E., \& Maurer, M. (2006). Focus on grammar. White Plains, NY: Pearson Longman.

SurveyMonkey. (2011). www.surveymonkey.com

Yates, L., \& Zielinski, B. (2009). Give it a go: Teaching pronunciation to adults. Sydney, Australia: AMEPRC. Available:

http:/ / www.ameprc.mq.edu.au/resources/classroom_resources/give_it_a_go

Zielinski, B. (2006). The intelligibility cocktail: An interaction between speaker and listener ingredients. Prospect, 21, 22-45. 